\title{
The Relationship between Orientations, Ethnocentrism and Parental Roles in Second Language Acquisition among Form Four Students of Fully Residential Schools in Terengganu
}

\author{
Aminuddin Hassan ${ }^{1, *}$, Wan Yusnita Wan Jusoh ${ }^{2}$ \\ ${ }^{1}$ Department of Foundations of Education, Faculty of Educational Studies, Universiti Putra Malaysia, Malaysia \\ ${ }^{2}$ Faculty of Educational Studies, Universiti Putra Malaysia, Malaysia
}

Received October 27, 2019; Revised December 30, 2019; Accepted January 15, 2020

Copyright $\subseteq 2020$ by authors, all rights reserved. Authors agree that this article remains permanently open access under the terms of the Creative Commons Attribution License 4.0 International License

\begin{abstract}
Based on a report by the Performance Management and Delivery Unit (PEMANDU) of the Prime Minister's Department in 2013, it can be known that 1191 secondary schools in Malaysia had exceeded 23\% of the failure rates in SPM English. Terengganu was one of the states highlighted and the statistic acquired from the Terengganu Education Department showed that about 5000 students failed in the subject in the past five years. Subsequent to this, a quantitative research was done to test the relationship of orientations, ethnocentrism and parental roles in English language acquisition of 275 students in five fully residential schools in Terengganu. A questionnaire adapted from the AMTB, MSLQ and GENE was used where the pilot test resulted in .788 Cronbach's Alpha. The findings conclude that the students were integratively and instrumentally orientated. Although there were positive correlations between ethnocentrism and SLA, a majority of the students managed to acquire the L2 excellently. There was a mild positive relationship between parental roles and the achievement of students in English. Total institution could best explain this result as students had limited time spent with their parents. These findings could help improve students' achievement in English in residential schools in other problematic states by using approaches that are integratively and instrumentally orientated.
\end{abstract}

Keywords AMTB, Ethnocentrism, GENE, Instrumental Orientation, Integrative Orientation, MSLQ, Parental Roles, Total Institution

\section{Introduction}

It was reported that more than forty-thousand Malaysian graduates from public universities, in 2011 alone, many of whom Malays from the rural areas, could not secure jobs in the private sector due to low proficiency in English (Hamzah, 2014). In a similar note, Yuen (2015) reported in The Star online of the poor standard of English among Malaysians at work. This affects all sectors and according to the Malaysian Employers Federation (MEF), the decline of English is prevalent across job industries and not isolated in any particular sector only. Consequently, it has become increasingly difficult to hire fresh graduates as the level of proficiency does not command the confidence of the employers to employ them and 200,000 unemployed graduates are out of work due to the problem.

In the National Education Blueprint (NEB) for 2013 to 2015, the second shift has clearly emphasised on ensuring every child is proficient in Bahasa Melayu and English Language by 2015 or in other words, to be bilingual. This shift is triggered from the worrying achievement of students mainly in the 2011 SPM Examination where only $28 \%$ of students achieved a minimum credit in SPM English paper against the Cambridge 1119 standard and undoubtedly, signifies the much lower than expected students' operational proficiency in English.

The vision of the blueprint is to ensure that by the end of Form Five, 70\% will score a minimum of credit in SPM against Cambridge 1119 standards. However, the National Cumulative Grade Point Average for SPM English Language paper has experienced a major drop in 2014 to 6.12 from 5.94 in 2013. This made headlines in the newspapers instantly, not just for its failure to reach the targeted point to indicate the good achievement but also 
signifying bigger issues to be corrected. This is part of implementation technicalities in English Language teaching and learning processes.

Fully-residential schools in Malaysia are also affected in terms of their achievements in the English language subject. To date, there is a strong number of 69 fully-residential schools or better known as "Sekolah Berasrama Penuh" (SBP) all over Malaysia. Although all SBPs reached the target of 100\% passes, they did not reach the standard target set for the subject by "Bahagian Pengurusan Sekolah Berasrama Penuh dan Sekolah Kluster" (BPSBPSK) or the Fully Residential School and Cluster School Management Division, Ministry of Education Malaysia which is 100\% A. From the recent SPM results, 38.67\% students achieved the highest of $\mathrm{B}+$ and the lowest of $\mathrm{E}$ grade from 10,517 students in English. Known for its high-quality education and academically excellent enrolment, SBPs in Malaysia are also in jeopardy, in terms of the students' proficiency and literacy.

\subsection{Objectives}

The general objective of the research is to clarify the problems faced by the fully-residential schools in Terengganu as to why they have failed to achieve the target of $100 \% \mathrm{~A}$ in the English. The specific objectives are to identify the orientation, ethnocentrism and parental roles of students to learn English and to investigate the relationship between orientations, ethnocentrism and parental roles of the students to learn English.

\subsection{Scope and Limitations}

This study focuses on the relationship of orientation, ethnocentrism and parental roles in the acquisition of second language and in this case, the English Language subject. The focus on these three variables will only be tested in their formal context of learning. Moreover, all the five fully residential schools in Terengganu will be the samples but only involving Form Four students from Terengganu.

It is crucial to the study to group the respondents according to the state of origin for validity of data. The data collection will only be done through group administered questionnaires adapting the work of Gardner (1985), Pintrich et al (1997), Lee (2012), McCroskey \& Neuliep (2012). The survey will only be done through the agreement by the schools' administration. No interviews or other methods of data collection will be applied.

\subsection{Assumptions}

The primary assumption in this study is that there are relationships between orientation, ethnocentrism, parental roles and English language acquisition in fully-residential schools in Terengganu and these variables will affect students' achievement in the subject.
It is also assumed that low proficiency students are present at fully residential schools in Terengganu as there is only a minimum requirement of C grade from PT3 examinations for the English language. This could be a contributing factor in their achievement in SPM too and most importantly, their overall interest in the subject.

\section{Literature Review}

\subsection{Second Language Acquisition (SLA)}

Saville-Troike (2016) defined SLA as the study of individuals and groups who are learning a language subsequent to their first one and the process of learning. However, Cook (2016) sees the process as where the L2 learners are attempting to communicate through a language that is not their own which highly depend on the social aspects of communications. Williams (2016) on the other hand, was rather technical on his understanding of SLA as he believes that acquisition of a language if done implicitly, involves the control over the learning task and input.

These definitions of SLA have given a perspective that it is a study of the what, how and why a person is able to understand and use a foreign language learned and the ideal success of language learners is to be competent and utilise the elements of target language in a communicative prospect. The what, how and why of SLA are the guides to seek the differences and substances of the language learned, the mental and cognitive process involved, the variability in learners and group related phenomena.

\subsection{SLA in Terengganu}

The Performance Management and Delivery Unit (PEMANDU) of the Prime Minister Office had highlighted schools in the states of Sabah, Kelantan, Terengganu and Kedah as the major contributors to the SPM English language failure rates in Malaysia (NST, 2013). It was identified that failures were particularly acute in the states mentioned and progressive actions should be taken to reduce the number of failing candidates in the states.

In relevance to the states mentioned, the Terengganu Education Department declared that 5500 or $27 \%$ of the students who sat for SPM in Terengganu failed in the English language subject based on statistics since 2010 (Bernama, 2014). Datuk A.Rahman Yahya of the State Economic Planning Unit had also stated that although Terengganu has consistently been among the top performer in national exams, the performance in English is not up to par with the national target (NST, 2015).

This is evident in the comparisons of the state and national Grade Point Average (GPA) for the English language subject (JPNT, 2015). Since 2011, the state GPA has been lower than the national GPA with the biggest gap of 0.44 point in the year 2011 and 2014 . 
In a similar statement, the state Education, Higher Education and Special Affairs Committee chairman, Ghazali bin Taib, saw the mastery of English among students of Terengganu, in primary and secondary schools alike, were not just weak but critical (Bernama, 2014). He explained that the acceptance of the people in Terengganu to converse in English on a daily basis is seen as rare and critical compared to other states on the West Coast, where the language is widely used in the public and social domain. The unhealthy culture of belittling others trying to use English language was seen as the barrier to succeed in the acquisition of the language especially when examination is the indicator.

In relation to the fully residential schools in Terengganu, even though with zero failures in the SPM English language paper from 2011 until 2015, there were two remote cases of $E$ grade recorded in the year 2011 and 2014. With an average of 665 SPM candidates each year, although students achieving A grade in the subject seemed to dominate the statistics, almost $50 \%$ of them only scored a minimum credit of $\mathrm{D}$ grade and highest credit of $\mathrm{B}+$ in SPM.

These so called 'academically excellent' students were offered a place in fully residential schools through a minimum B grade in their UPSR or PT3 results. Hence, it somehow raises questions on their actual language ability and what the problem seem to be that hinders their progress.

\subsection{Socio-Educational Model}

Triggered by the question on how some people can learn a foreign language quickly and expertly but some failed, Gardner and his colleagues (1972) centred their focus studying individual differences in foreign language skills in adolescents in a school setting. Based on a series of studies carried out for over twelve years, a sociopsychological theory of second and foreign language called the Socio-Educational Model was later developed in 1985.

The model was first proposed in 1974 and undergone revisions to stress the idea that languages involve the acquisition of skills or behaviour patterns which are a salient characteristic of another culture (Gardner, 1985).

Figure 1 is a schematic representation of Gardner's 1985 revised version of the model. It focuses on four sections mainly External Influences, Individual Differences, Language Acquisition Context and Outcomes.

This study will focus on the relationship between parental roles and ethnocentrism as external influences in the acquisition of L2 and also the relationship between individual differences aspect which is the students' orientations in the SLA.

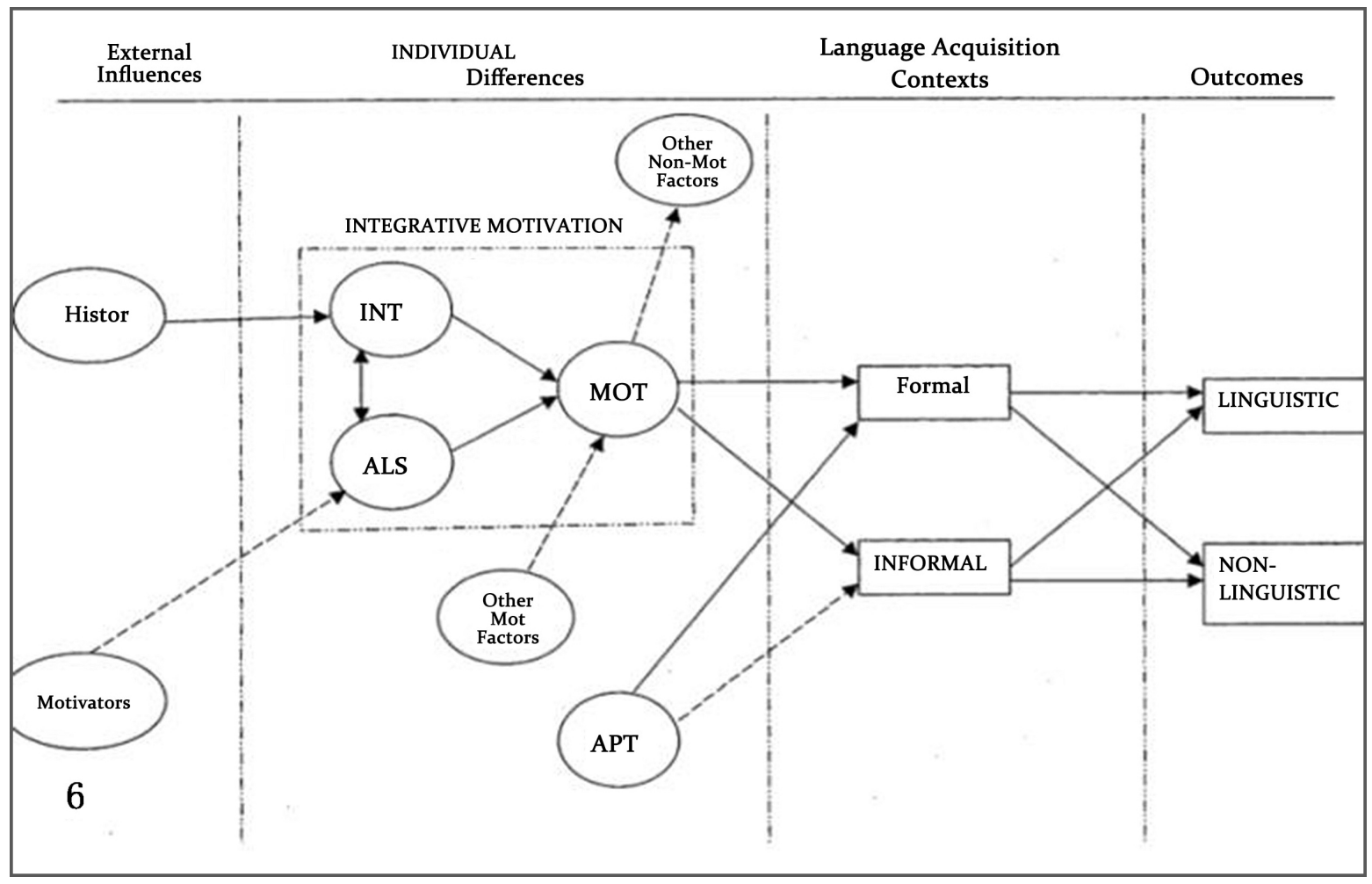

Figure 1. Revised Socio-Educational Model (Gardner, 2001) 


\subsection{Orientation, Ethnocentrism, Parental Roles and SLA}

Ali, Wyatt and Van Laar's (2015) study revealed that the effect of motivation is significantly greater when it is supported by integrative orientation which has a direct positive impact on English achievement. Similarly, Chiang (2018) has also proven a positive correlation between integrative orientation and English achievement in his study among Taiwanese students. This clearly supports Gardner's theory that integrative orientation has a deeper impact on language learners to expend effort to master the target language.

On the other hand, there are also studies which resulted in more instrumentally orientated participants. On and Cheon's (2017) research among Korean learners resulted in increased instrumental orientation compared to integrative orientation. In addition, a similar result was revealed in a study by Aladdin (2017) where participants showed higher instrumental orientation. The result indicated that learners are interested to learn L2 due to its practical reasons to pass the subject or to find a good job.

Interestingly, there were also studies that resulted in both integrative and instrumental orientation among its participants. In a study by Wahidi, Samad, Fitirani \& Samad (2018), the students have both integrative and instrumental orientation where the students agree it is important to have better understanding of the way native speakers think and the target language is the sole resource for their dream career. The result is similar to Coskun's (2018) study on motivation of foreign language learning of 1222 students in Albania.

In regard to ethnocentrism, research on the correlation between ethnocentrism and language learning has on many occasions came up negative. Meeusen, de Vroome and Hooghe's (2013) research findings indicated there is a negative relation between education attainments and levels of ethnocentrism, proving that the higher level of education an individual attains, the lower the level of ethnocentrism he has. Another research was carried out among 630 Japanese learners with low proficiency in English to test the validity of Gardner's socio educational theory in a monolingual context in Japan (Lee, 2012). The results also showed negative correlations between ethnocentrism and language learning.

Nonetheless, in a study to assess the degree of students' ethnocentrism and English as a Foreign Language interests, $\mathrm{Su}$ (2018) revealed that there is a significant relation between the two factors. Although the highest correlation found was between learners' interaction engagement, ethnocentrism is related to intercultural sensitivity which affects the students' readiness and interests in learning English.

This is similar to Lajos' (2018) research on the consequences of multiculturalism on high school students in Serbia. With the assumption that the degree of multilingualism could be associated with the level of generalised ethnocentrism, the study resulted in the group with a higher degree of multilingualism showing a lower level of ethnocentrism. It can be concluded that openness to learning other languages and treating them as important carriers of culture can help improve an individual's language acquisition.

The role of parents in academic achievement is undeniable in every level of education. Elementary school is where students can progress successfully and the first year is crucial for children to acquire basic reading and writing skills. Parental involvement is needed yet some parents are not knowledgeable on how to be involved and it was found that families with high socio-economic status are better at supporting students, working together and helping them at home (Cakiroglu \& Kuruyer, 2012). Studies on parental involvement and influence in academic performance of their children have shown many positive correlations (Porumbu \& Necsoi, 2013), as well as with the school choice for their children (McCarthy, 2016; Berti, Mameli, Molinari \& Speltini, 2016).

In addition, a study done by Erikson (2018) on approximately 28000 Swedish school children to identify the association between parental education and educational attainment of their children has revealed that parental education is more highly associated with educational attainment than their earnings. This proves that having educated parents influence the education of their children too.

On the other hand, Mata, Pedro and Peixoto (2018) related through the result of their study on parental support and students' motivational orientation, that if the children experience a positive and enjoyable emotion during interactions with their parents pertaining to learning, they will be more motivated to learn and perform in school.

\section{Methods}

This study applies the descriptive correlational design to test the hypotheses using a sample drawn from the population of form four students from all the five boarding schools in Terengganu.

A total number of 275 students were taken as the subjects for this study stratified to students from the state of Terengganu having both Terengganu parents, studying in these schools and excluding students of other states. This is to gain control over the validity of the data concerning only the students of Terengganu without interference of other states.

For this study, a questionnaire was designed and utilised adapting orientation instruments from Gardner and Lambert (1985) and Pintrich et al (1997); ethnocentrism by McCroskey \& Neuliep (2012) and the parental roles instruments are from Gardner and Lambert (1985). The first part of the questionnaire (Section A) was the demographic background to be filled by participants which 
include:

1. Gender

2. $\quad$ PT3 English Language Exam Results

3. Students' usage of English

4. Parents' education level

5. Parents' frequency of using English

The second part of the questionnaire (Section B) used a 5 Point Likert Scales response from 1 (strongly disagree) to 5 (strongly agree) where participants answered on the construct of:

1. Integrative orientation (items $6,10,11,12,14,16$, $18,20)$

2. Instrumental orientation (items 7, 8, 9, 13, 15, 17, 19, 21)

3. Ethnocentrism (items 22 until 47)

4. Parental roles (items 48 until 57)

\subsection{Results}

\subsubsection{Orientation}

Table 1. Summary of Significant Correlations between Orientations and Second Language Acquisition (SLA) According To Orientation Types

\begin{tabular}{|c|c|c|c|}
\hline Item no & $\begin{array}{c}\text { Orientation } \\
\text { type }\end{array}$ & $\begin{array}{c}\text { Correlation } \\
\text { coefficient }\end{array}$ & P value \\
\hline $\mathbf{1 4}$ & $\begin{array}{c}\text { INTEGRA } \\
\text { TIVE }\end{array}$ & $-.135^{*}$ & .025 \\
\hline $\mathbf{1 6}$ & $\begin{array}{c}\text { INTEGRA } \\
\text { TIVE }\end{array}$ & $-.195^{* *}$ & .001 \\
\hline $\mathbf{1 8}$ & $\begin{array}{c}\text { INTEGRA } \\
\text { TIVE }\end{array}$ & $\mathbf{- . 1 2 1 *}$ & $\mathbf{. 0 4 5}$ \\
\hline $\mathbf{2 0}$ & $\begin{array}{c}\text { INTEGRA } \\
\text { TIVE }\end{array}$ & $\mathbf{- . 1 2 5 *}$ & $\mathbf{. 0 3 9}$ \\
\hline $\mathbf{1 7}$ & $\begin{array}{c}\text { INSTRUM } \\
\text { EN-TAL }\end{array}$ & $\mathbf{- . 1 2 7 *}$ & .035 \\
\hline $\mathbf{1 9}$ & $\begin{array}{c}\text { INSTRUM } \\
\text { EN-TAL }\end{array}$ & $\mathbf{- . 1 2 3 *}$ & $\mathbf{. 0 4 1}$ \\
\hline
\end{tabular}

$(\mathrm{N}=275$, **Correlation is at the 0.01 level (2-tailed), *Correlation is at the 0.05 level (2-tailed)

The results reveal that there is a significant relationship between orientation and SLA, hence the hypothesis is accepted. Nevertheless, the relationship between both orientations and SLA is modest/mild based on the interpretation of correlation suggested by Dancey and Reidy (2007). Consequently, with the presence of significant correlations between integrative and instrumental orientation in SLA in this research, it is believed that the presence of both orientations is the evidence of the humans' complexity as certain might feel both integrative and instrumental reasons apply to them or neither reasons apply (Gardner, 2010).

\subsubsection{Ethnocentrism}

The results reveal that there is a significant relationship between ethnocentrism and SLA, hence the hypothesis is accepted. Nevertheless, the relationship between ethnocentrism is modest/mild or considered weak based on the interpretation of correlation by Dancey and Reidy (2007). Although 7 out of 26 correlations were statistically significant and were greater or equal to rs $(273)=+.13, p<.05$, two-tailed, they do not affect the respondents' SLA. This is true as 199 (72.4\%) respondents scored A (Excellent) grade, 58 (21.1\%) respondents scored B (Good) grade and only 18 (6.5\%) respondents scored C (Satisfactory) in PT3 English language exam.

Table 2. Summary of Significant Correlations between Ethnocentrism and SLA

\begin{tabular}{|c|c|c|c|}
\hline $\begin{array}{c}\text { Item } \\
\text { no }\end{array}$ & Statement & $\begin{array}{c}\text { Correlation } \\
\text { coefficient }\end{array}$ & P value \\
\hline 22 & $\begin{array}{c}\text { Most other cultures are } \\
\text { backward compared to } \\
\text { my culture }\end{array}$ & $.167 * *$ & .006 \\
\hline 27 & $\begin{array}{c}\text { I am not interested in the } \\
\text { values and customs of } \\
\text { other cultures }\end{array}$ & $.145^{*}$ & .016 \\
\hline 29 & $\begin{array}{l}\text { Most people from other } \\
\text { cultures just do not know } \\
\text { what is good for them. }\end{array}$ & $.130 *$ & .031 \\
\hline 39 & $\begin{array}{l}\text { I do not cooperate with } \\
\text { people who are different }\end{array}$ & $.193 * *$ & .001 \\
\hline 41 & $\begin{array}{c}\text { I do not trust people who } \\
\text { are different }\end{array}$ & $.146^{*}$ & .015 \\
\hline 42 & $\begin{array}{c}\text { I dislike interacting with } \\
\text { people from different } \\
\text { cultures }\end{array}$ & $.151 *$ & .012 \\
\hline 46 & $\begin{array}{c}\text { It will not be very } \\
\text { inconvenient even if they } \\
\text { cannot speak English }\end{array}$ & $.167^{* *}$ & .006 \\
\hline
\end{tabular}

\subsubsection{Parental Roles}

Table 3. Summary of Significant Correlations between Parental Roles and SLA

\begin{tabular}{|c|c|c|c|}
\hline $\begin{array}{c}\text { Item } \\
\text { no }\end{array}$ & Statement & $\begin{array}{c}\text { Correlation } \\
\text { coefficient }\end{array}$ & P value \\
\hline 55 & $\begin{array}{c}\text { My parents have stressed } \\
\text { the importance English } \\
\text { will have for them when } \\
\text { they leave school. }\end{array}$ & $\mathbf{. 1 4 8 *}$ & $\mathbf{. 0 1 4}$ \\
\hline
\end{tabular}

( $\mathrm{N}=275,{ }^{* *}$ Correlation is at the 0.01 level (2-tailed), ${ }^{*}$ Correlation is at the 0.05 level (2-tailed)

Overall, the results revealed that there is a significant relationship between parental roles and SLA, hence the hypothesis is accepted. Nevertheless, the relationship between parental roles and SLA is modest/mild or considered weak based on the interpretation table of correlation by Dancey and Reidy (2007).

\section{Discussions}

In this research the respondents were integratively and instrumentally orientated. These students highly believed that by learning English, it will be helpful for them to communicate with more people. This is true in their context of fully residential school environment where they 
participate in activities involving other cultural groups. Not only will they be able to meet foreign students but it will help them to converse with other Malaysians who speak English too in these programs.

Students in residential schools are exposed to activities that require them to converse in English, be it in academic or co-academic activities. Annual programmes like Hari Kecemerlangan Sekolah Berasrama Penuh Debates, Fully Residential Schools Symposium and Malaysia International Young Inventors Olympiad to name a few, are co-academic activities that are prestigious and requires high English fluency. This challenges the ability and desire of students in order to participate, hence, they are internally driven to learn and excel in their L2 which is English.

These national and international programmes also involve the participation of foreign students which exposed students to a variety of communities of the world. Therefore, the ability to converse in English will definitely provide an advantage to them to interact with these foreign students to share their interests to have closer liaison with another language community.

As the relationship between ethnocentrism and SLA is modest in the current research, this explains the reason why a majority of the respondents excel in their SLA where they scored A in their PT3 English language exam. A correlation coefficient done between ethnocentrism and SLA among respondents who scored B and C however resulted in negative significant relationship.

The composition of all Malays in the selected fully residential schools may have also contributed to the result. Being in the same ingroups with similar cultural traits has minimised the differences that could contribute to major clashes in identity and understanding which help the students to excel in their English. Moreover, the fact that these respondents are in a total institutionalised surrounding has somehow moulded them into a unit who understand and follow certain flow of thinking set by the administration.

Although the findings showed that a majority of the respondents have difficulties to cooperate with people who are different, it does not affect their overall performance in the language. This clearly does not support Gardner and Lambert's belief that having a strong ethnocentricity will hinder the learner's success in learning a L2. With integrative orientation, these respondents have outweighed their ethnocentricity which leads to their success in mastering the language.

Even if the respondents have unfavourable attitudes towards the language or specifically the values and customs of the native speaker, they could succeed in acquiring English. Moreover, although the respondents are not interested in the values and customs of other cultures, their awareness of the importance of English for their future have geared them to score well in the PT3 exam.
Based on the findings of this research, it is found that parental roles only have weak relationship in SLA. It is evident in the research that the respondents' parents are aware of the importance of mastering English as they have stressed the idea to the respondents. The parents have played their roles consciously to encourage the respondents to learn English and to do well in it. This is because they know that English will benefit their children when they leave school. As parents are aware of this, it could be explained that the respondents' admission to fully residential schools is also decided upon the idea that these schools could provide a conducive environment to use English.

The weak relationship between parental roles and SLA could be caused by the limited involvement of parents in their SLA due to total institution. Boarding school is a form of total institution and as the respondents are fully residential schools students, their day's activities are tightly scheduled and carried out in a large batch of other students who are required to do the same thing together. Hence, parental roles are weak as these respondents spend their time mostly with friends and teachers in the schools but have limited access to their parents.

\section{Conclusions}

This research concluded that the respondents are both integratively and instrumentally orientated. This significantly suggests that the respondents are motivated to learn the L2 to identify with the other language and also for its pragmatic reasons. The positive significant relationship between ethnocentrism and parental roles in SLA found in this research support the concept of complex social and personal variables that can influence SLA.

Ethnocentrism represents the social-cultural milieu in which the respondents live and parental roles are related to the respondents' personal family background. Gardner (2005) clearly explained that learners, in a form of their cultural background, beliefs on the value and need of learning the language, expectations about possible success and differences in their personal backgrounds and histories will produce linguistic and non-linguistic outcomes. In this case, the linguistic outcome is majority of the respondents were successful at their mastery of the L2 where 199 (72.4\%) of them scored A which is an excellent level.

This research resulted in positive significant relationships between orientations (integrative and instrumental), ethnocentrism and parental roles in SLA where all the variables have modest correlations to SLA. However, having majority of the respondents excelled in their acquisition of the L2 can only be clarified by the context of the formal and informal learning of L2 which is in fully-residential schools. Dornyei (2005) explained that school is a specific group context with its own group norms 
with its overt and covert rules and routines that may include explicit school regulations and unofficial norms of learner behaviour. Receiving formal and informal language lessons in the environment of fully-residential school possibly involves other affective variables which explain the modest correlations between all variables.

\section{REFERENCES}

[1] Ali, M., Wyatt, M., \& Van Laar, D. (2015). Pakistani postgraduate students' orientations for learning English as a second language: A factor analytic study. System, 51, 77-87.

[2] Bernama. (2014). Command of English Language among the Students in Terengganu Still Weak. Retrieved from http://www.newsarawaktribune.com/news/29491/Comman d-of-English-language-among-students-in-Terengganu-still -weak/

[3] Berti, C., Mameli, C., Speltini, G., \& Molinari, L. (2016). Teacher justice and parent support as predictors of learning motivation and visions of a just world. Issues in Educational Research, 26(4), 543-560.

[4] Cakiroglu, A., \& Kuruyer, H. G. (2012). First grade Elementary School Student's Family Involvement in the Process of Reading and Writing Skills Acquisition. Procedia - Social and Behavioral Sciences, 46, 5588-5592. https://doi.org/10.1016/j.sbspro.2012.06.480

[5] Chiang, I. C. N. (2018). Principles for Deep Knowledge and its Relationships with Integrative Orientation, Motivational Intensity and English Learning Achievement

[6] Cook, V. (2016). Second Language Learning and Language Teaching. New York: Routledge, https://doi.org/10.4324/9 781315883113

[7] Coskun, L. (2018). Investigating the influences of integrative and instrumental motivation on foreign language learning: a case of albanian public university. PROCEEDINGS BOOK, 50.

[8] Dancey, C., \& Reidy, J. (2004). Statistics Without Maths for Psychology.

[9] Dornyei, Z. (2012). The Psychology of Second Language Acquisition. Oxford University Press.

[10] Erikson, R. (2016). Is it enough to be bright? Parental background, cognitive ability and educational attainment. European Societies, 18(2), 117-135.

[11] Gardner, R. C. (2001). Language Learning Motivation: The Student, the Teacher, and the Researcher. Texas Papers in Foreign Language Education, 6, 1-18., 6, 1-18. https://doi.org/10.1177/0261927X99018004004

[12] Gardner, R. C. (1985). Social Pscyhology and Second Language Learning.Pdf.

[13] Gardner, R. C. (2005). Attitude / Motivation Test Battery : International AMTB Research Project. The University of
Western Ontario, http://publish.uwo.ca/ gardner/docs/engl ishamtb.pd.

[14] Gardner, Robert C.; Lambert, W. E. (1972). Attitudes and Motivation in Second-Language Learning. Massachusetts: Newbury House Publishers, Inc.

[15] Lajos Göncz (2018) Generalised ethnocentrism among high-school students in a multicultural setting: the role of the degree of multilingualism, Journal of Multilingual and Multicultural Development, 39:3, 224-239, DOI: 10.1080/01434632.2017.1355371

[16] Lee, S. im. (2012). Japanese Learners’ Underlying Beliefs Affecting Foreign Language Learners' Motivation: New Perspectives of Affective Factors Mechanism Soo im Lee, (4), 40. Retrieved from http://afrasia.ryukoku.ac.jp/english/ publication/upfile/WP004.pdf

[17] Malaysia Education Blueprint, M. (2013). Malaysia Education Blueprint 2013 - 2025. Education, 27(1), 1-268. https://doi.org/10.1016/j.tate.2010.08.007

[18] Mata, L., Pedro, I., \& Peixoto, F. J. (2018). Parental Support, Student Motivational Orientation and Achievement: The Impact of Emotions. International Journal of Emotional Education, 10(2), 77-92.

[19] McCarthy, M. (2016). Parental choice of school by rural and remote parents. Issues in Educational Research, 26(1), 29-44.

[20] Meeusen, C., de Vroome, T., \& Hooghe, M. (2013). How does education have an impact on ethnocentrism? A structural equation analysis of cognitive, occupational status and network mechanisms. International Journal of

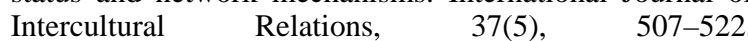
https://doi.org/10.1016/J.IJINTREL.2013.07.002

[21] Neuliep, J. W. (2017). Ethnocentrism. In the International Encyclopedia of Intercultural Communication, Y. Y. Kim (Ed.). doi:10.1002/9781118783665.ieicc0030

[22] Neuliep, J. W. (2017). 15 Ethnocentrism and intercultural communication. Intercultural communication, 9, 331.

[23] Oh, K., \& Cheon, S. (2017). Motivational Orientations and Variables of Korean Learners. The Korean Language in America, 20(2), 131-151. doi:10.5325/korelangamer.20.2.0 131

[24] Porumbu, D., \& Necşoi, D. V. (2013). Relationship between Parental Involvement/Attitude and Children's School Achievements. Procedia - Social and Behavioral Sciences, 76, 706-710. https://doi.org/10.1016/j.sbspro.20 13.04.191

[25] Shiraev, Eric; Levy, D. (2004). Cross-Cultural Psychology: Critical Thinking and Contemporary Applications (Second). USA: Pearson Education, Inc.

[26] Su, Y. C. (2018). Assessing Taiwanese college students' intercultural sensitivity, EFL interests, attitudes toward native English speakers, ethnocentrism, and their interrelation. The Asia-Pacific Education Researcher, 27(3), 217-226.

[27] Wahidi, R., Samad, I. A., Fitriani, S. S., \& Samad, N. M. A. (2018). Orientations and Motivations of Learning Foreign 
Language on the Students of Graduate Program at Syiah Kuala University. International journal of linguistics and humanities, 1(2), 22-34.

[28] Din, N.M., Ayub, A.F.M \& Tarmizi, R.A (2016). Influence of parental involvement and peer support on mathematics engagement among Malaysian secondary school students. Malaysian Journal of Mathematical Sciences. 10(S) 175-185. 